\title{
Calmodulin and calmodulin-binding proteins of Rhodosporidium toruloides, a basidiomycetous yeast
}

\author{
Yusen LiU, Osamu Ohki, Yoshiaki Azuma, Tamaki Tachikawa, Eiko Tsuchiya, \\ SAKUZO FuKui $\dagger$ and ToKICHI MIYAKaWA*
}

Department of Fermentation Technology, Faculty of Engineering, Hiroshima University, Saijo, Higashi-Hiroshima, 724 Japan

(Received 25 May 1989; revised 29 August 1989; accepted 27 September 1989)

\begin{abstract}
Calmodulin (CaM)-interacting proteins of Rhodosporidium toruloides, a basidiomycetous yeast, were studied. CaM-binding proteins isolated from the soluble cell extract of vegetative cells and gamete cells (matingpheromone-treated cells) by CaM-Sepharose affinity chromatography were analysed by sodium dodecylsulphatepolyacrylamide gel electrophoresis to compare the molecular species of CaM-binding proteins of the two cell types. The major CaM-binding proteins of the vegetative cells had molecular masses of 103 and $96 \mathrm{kDa}$. In the pheromone-treated cells, in addition to the bands seen in the vegetative cells, prominent bands of 40 and $38 \mathrm{kDa}$ and minor bands of 92 and $60 \mathrm{kDa}$ were present. The bands of CaM-binding proteins present in both cell types were more intense in the gamete cells. CaM-binding proteins of total cell extracts were also detected on acrylamide gels by a gel overlay method using ${ }^{125} \mathrm{I}-\mathrm{CaM}$ as the probe. The results obtained by the two procedures suggested that various CaM-binding proteins are present in the yeast cell, and the expression of many CaM-binding protein genes is altered by the mating pheromone. $\mathrm{Ca}^{2+}$ and $\mathrm{CaM}$-dependent protein kinase activity was detected in the $\mathrm{CaM}$ affinity-purified proteins. After incubation under conditions for protein phosphorylation by the kinase, the enzyme no longer required the activators, indicating that the enzyme activity is modulated by endogenous phosphorylation. A protein of $60 \mathrm{kDa}$ was labelled by endogenous phosphorylation in a $\mathrm{Ca}^{2+} / \mathrm{CaM}$-dependent manner, indicating that the labelled protein may be the $\mathrm{Ca}^{2+} / \mathrm{CaM}$-dependent protein kinase or else be involved in its regulation.
\end{abstract}

\section{Introduction}

The process of mating between haploid cells of two compatible mating types ( $a$ and $A$ ) of Rhodosporidium toruloides, a basidiomycetous yeast, is initiated by a mating-type-specific mating pheromone secreted by the haploid cells (Abe et al., 1975). Rhodotorucine $A$, a farnesylated peptide mating pheromone produced by mating type $A$ cells (Kamiya et al., 1979) induces a very rapid and transient influx of $\mathrm{Ca}^{2+}$ into the cells of mating type $a$ from the medium (Miyakawa et al., 1985, 1986). The mating pheromone induces cascade reactions that result in sexual differentiation for mating which could be triggered by the transient rise of intracellular free $\mathrm{Ca}^{2+}$.

Calcium ions play an important role in the regulation of specialized cells in response to diverse extracellular signals such as hormones, growth factors and neurotrans-

$\dagger$ Present address: Department of Biotechnology, Faculty of Engineering, Fukuyama University, Fukuyama, 729 Japan.

Abbreviations: CaM, calmodulin; TFP, trifluoperazine. mitters. An early event in the action of these regulatory agents is a transient increase in the intracellular free $\mathrm{Ca}^{2+}$ level (Weiss et al., 1980). In most cases, the regulatory activities of $\mathrm{Ca}^{2+}$ are mediated by calmodulin $(\mathrm{CaM})$, a highly conserved low-molecular-mass $\mathrm{Ca}^{2+}$ binding protein. Upon binding $\mathrm{Ca}^{2+}, \mathrm{CaM}$ undergoes conformational changes revealing hydrophobic sites that enable binding to a number of target proteins whose activities are regulated by the $\mathrm{Ca}^{2+} / \mathrm{CaM}$ complex.

In the ascomycetous yeast Saccharomyces cerevisiae, $\mathrm{Ca}^{2+}$ is suggested to be involved in cell cycle progression (Baum et al., 1986). Recently, CaM genes of $S$. cerevisiae (Davis et al., 1986) and Schizosaccharomyces pombe (Takeda \& Yamamoto, 1987) have been cloned. It was demonstrated genetically that $\mathrm{CaM}$ is essential for the growth of the yeast cells (Davis et al., 1986; Takeda \& Yamamoto, 1987; Ohya \& Anraku, 1989). Identification and characterization of $\mathrm{CaM}$-interacting proteins will be important to elucidate $\mathrm{Ca}^{2+} / \mathrm{CaM}$-mediated regulatory processes. However, little is known about the identity of proteins that interact with $\mathrm{CaM}$ in yeast. 
We describe here the isolation and preliminary characterization of $\mathrm{CaM}$-binding proteins in soluble cell extracts of haploid vegetative cells and sexually differentiated cells (mating pheromone-treated cells) of $R$. toruloides. The presence of an autoregulatory $\mathrm{Ca}^{2+} / \mathrm{CaM}$ dependent protein kinase in the CaM-binding protein fraction is also described.

\section{Methods}

Micro-organisms and growth conditions. The haploid strains of Rhodosporidium toruloides IFO 0880-MI057 (mating type a) and IFO 0559-M919 (mating type $A$ ) described previously by Abe et al. (1975) were used. The cells were grown aerobically in YPG medium (Miyakawa et al., 1982). Gamete cells were prepared by incubation of $2 \times 10^{9}$ vegetative cells (mating type $a$ ) with rhodotorucine $A$ at concentrations of $1 \times 10^{7}$ cells ml $^{-1}$ and $20 \mathrm{U} \mathrm{ml}^{-1}$, respectively, for $3 \mathrm{~h}$ at $28^{\circ} \mathrm{C}$. One unit of activity $(\mathrm{U}) \mathrm{ml}^{-1}$ is defined as the pheromone concentration which gives the characteristic morphological change in $30 \%$ of the assay cells (Miyakawa et al., 1982).

Preparation of CaM. Bovine brain CaM was purified according to the method of Gopalakrishna \& Anderson (1982). $R$. toruloides CaM was purified to homogeneity from the soluble fraction by heat treatment $\left(5 \mathrm{~min}\right.$ at $100^{\circ} \mathrm{C}$ ) followed by phenyl Sepharose hydrophobic affinity chromatography

Radiolabelling of $\mathrm{CaM}$. CaM was labelled with ${ }^{125}$ I using BoltonHunter reagent as described by Bolton \& Hunter (1973). Labelled CaM was purified by hydrophobic affinity chromatography.

Preparation of CaM-binding proteins. CaM-binding proteins were prepared from the soluble cell extract of $R$. toruloides (about $2 \times 10^{9}$ cells) by CaM-Sepharose affinity chromatography as described previously for Saccharomyces cerevisiae CaM-binding proteins (Miyakawa et al., 1989).

Protein kinase assay. Protein kinase activity was measured in a reaction mixture $(100 \mu \mathrm{l})$ containing $20 \mathrm{mM}-\mathrm{Tris} / \mathrm{HCl}(\mathrm{pH} 7.0), 10 \mathrm{~mm}-$ $\mathrm{MgCl}_{2}, 1 \mathrm{~mm}$-dithiothreitol, $0.02 \mathrm{~mm}-\left[\gamma^{-32} \mathrm{P}\right] \mathrm{ATP}(2 \mu \mathrm{Ci}, 74 \mathrm{kBq})$ and $10 \mu \mathrm{g}$ each of $\kappa$-casein and bovine serum albumin (BSA). When

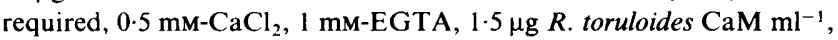
or $50 \mu \mathrm{M}$-trifluoperazine (TFP) were added. The reaction was initiated by the addition of labelled ATP to the mixture prewarmed at $28^{\circ} \mathrm{C}$. After incubation at $28^{\circ} \mathrm{C}$ (usually for $10 \mathrm{~min}$ ), the mixture was applied quickly onto a piece of filter paper (diameter, $23 \mathrm{~mm}$; Whatman $3 \mathrm{MM}$ paper) and immersed immediately in $10 \%(\mathrm{w} / \mathrm{v})$ trichloroacetic acid (TCA) at $100{ }^{\circ} \mathrm{C}(10 \mathrm{ml}$ per filter $)$. The filters were then washed three times with ethanol $(5 \mathrm{~min}$ for each rinse, $10 \mathrm{ml}$ per filter). The radioactivity on the filter was determined by liquid scintillation counting. To determine the effect of protein preincubation on the kinase activity, CaM-binding proteins were prephosphorylated under various conditions similar to those for the kinase assay, except that phosphorylation was carried out with unlabelled ATP $(0.02 \mathrm{mM})$ in the absence of the exogenous substrate ( $\kappa$-casein). After incubation, the enzyme activities were measured as described above by adding $2 \mu \mathrm{Ci}$ $\left[\gamma^{-32}\right.$ P]ATP $\left(4000 \mathrm{Ci} \mathrm{mmol}^{-1}, 148 \mathrm{TBq} \mathrm{mmol}^{-1}\right)$. Total and $\mathrm{Ca}^{2+} /$ $\mathrm{CaM}$-independent protein kinase activities were measured in the presence of $0.5 \mathrm{mM}^{-\mathrm{CaCl}_{2}}$ and $1.5 \mu \mathrm{g} \mathrm{CaM} \mathrm{ml}^{-1}$, and $1 \mathrm{mM}-\mathrm{EGTA}$ and $50 \mu \mathrm{M}$-TFP, respectively.

Analysis of phosphorylated proteins. CaM-binding proteins were phosphorylated with $\left[\gamma^{-32} \mathrm{P}\right] \mathrm{ATP}\left(4000 \mathrm{Ci} \mathrm{mmol}^{-1}, 148 \mathrm{TBq} \mathrm{mmol}^{-1}\right)$ by incubation in the presence and absence of $\mathrm{Ca}^{2+} / \mathrm{CaM}$ as described above for the protein kinase assay, except that $\kappa$-casein was omitted from the incubation mixture. Phosphorylated proteins were precipitated in a microfuge tube, with $20 \mu \mathrm{g}$ BSA added as carrier, by the addition of $100 \mu \mathrm{l}$ of $10 \%(\mathrm{w} / \mathrm{v}) \mathrm{TCA}$. The precipitates were collected by centrifugation in a microfuge and rinsed three times with $0.5 \mathrm{ml}$ ethanol. The washed precipitates were then dissolved in sample buffer and analysed by sodium dodecylsulphate-polyacrylamide gel electrophoresis (SDS-PAGE) as described by Laemmli (1970), using $12.5 \%$ $(w / v)$ gels. The radioactivity on the gel was detected by autoradiography. Gels were calibrated using human erythrocyte membrane proteins and BSA as molecular mass markers.

Gel overlay method. Samples of cell extracts ( $18 \mu \mathrm{g}$ protein) were resolved by SDS-PAGE in $12.5 \%$ gels and the CaM-binding proteins were detected by the gel overlay method described by Glenney \& Weber (1983).

\section{Results and Discussion}

\section{CaM from $R$. toruloides}

$\mathrm{CaM}$ has been purified to homogeneity from various sources in a single step using hydrophobic affinity chromatography (Gopalakrishna \& Anderson, 1982). This procedure, which exploits the characteristic $\mathrm{Ca}^{2+}$ dependent change of hydrophobicity of $\mathrm{CaM}$, was effective for the purification of CaM from $R$. toruloides. With an additional step of heat-treatment of the cell extract before the affinity chromatography step, a practically homogeneous preparation of $\mathrm{CaM}$ was obtained (Fig. 1). Usually, about $1 \mathrm{mg} \mathrm{CaM}$ was obtained from a 51 culture $\left(4 \times 10^{11}\right.$ cells or $2.0 \mathrm{~g}$ protein in the cell extract). CaM from $R$. toruloides changed its electrophoretic mobility when electrophoresed in the presence and absence of $\mathrm{Ca}^{2+}$, as occurs with $\mathrm{CaM}$ from many other sources (Fig. 1).

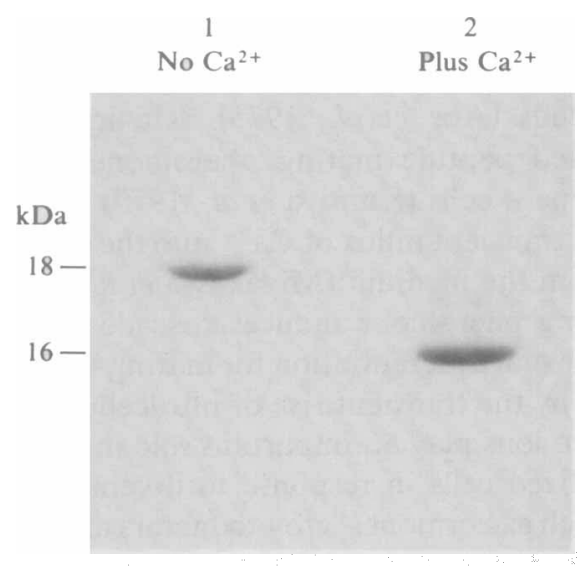

Fig. 1. CaM isolated from $R$. toruloides. Samples ( $4 \mu \mathrm{g}$ protein) purified by hydrophobic affinity chromatography were analysed by SDS-PAGE $\left(12.5 \%\right.$ gel). The sample contained $1 \mathrm{~mm}-\mathrm{EGTA}$ (lane 1 ) or $1 \mathrm{~mm}-\mathrm{Ca}^{2+}$ (lane 2). 

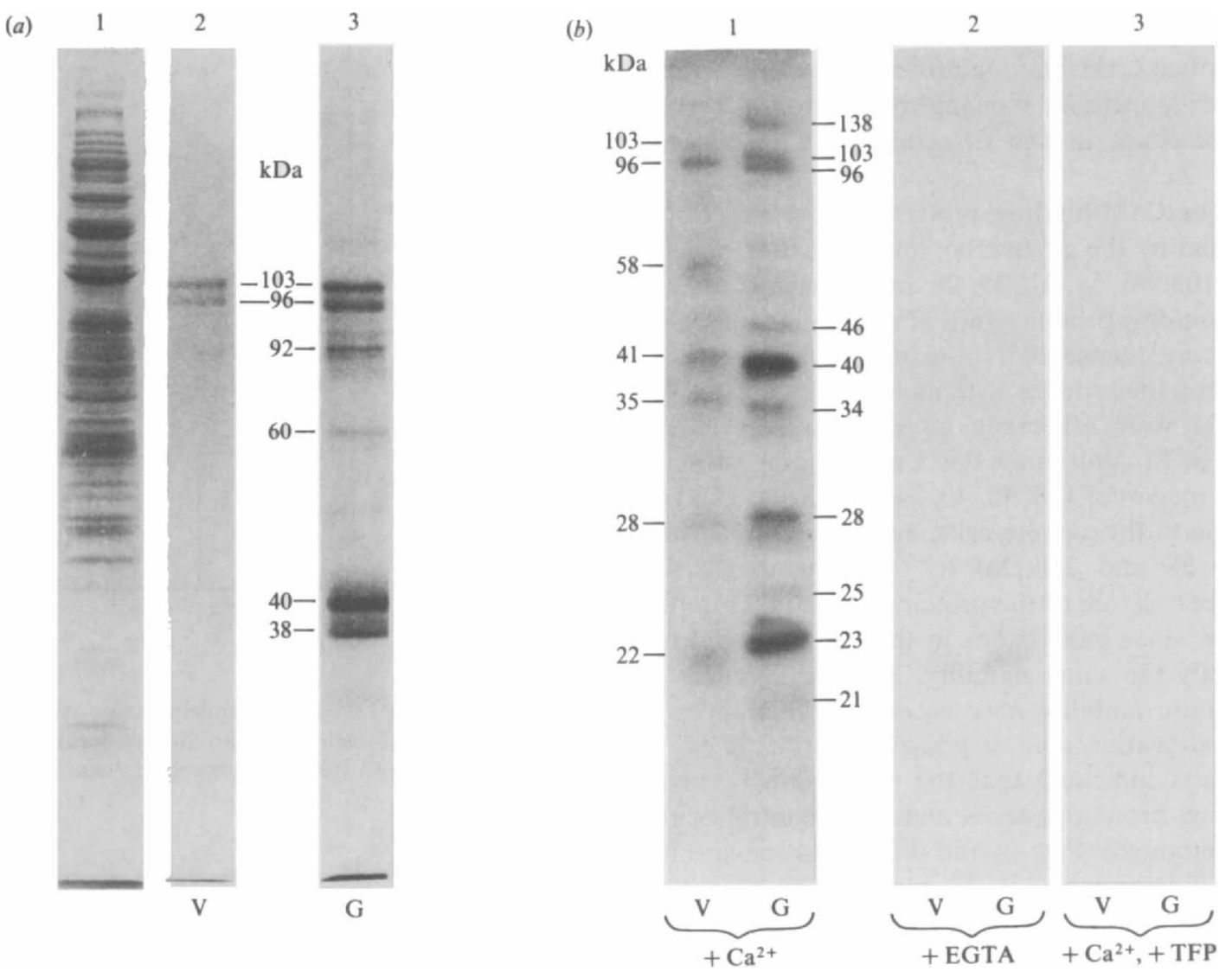

Fig. 2. CaM-binding proteins of $R$. toruloides. (a) CaM-binding proteins affinity-purified from vegetatıve cells $(\mathrm{V})$ and gamete cells $(\mathrm{G})$ were separated by SDS-PAGE $(7.5 \% \mathrm{gel})$ and the gel was stained with Coomassie brilliant blue. 1 , Total cell extract of vegetative cells; 2, CaM-binding proteins of vegetative cells; $3, \mathrm{CaM}$-binding proteins of gamete cells. (b) Soluble extracts purified from vegetative and gamete cells (each containing $60 \mu \mathrm{g}$ protein) were separated by SDS-PAGE and the CaM-binding proteins were detected by the gel overlay method $(12.5 \% \mathrm{gel})$ as described in the text. The gels were incubated with [ $\left.{ }^{125} \mathrm{I}\right] \mathrm{CaM}$ in the presence of $1,1 \mathrm{mM}-\mathrm{Ca}^{2+} ; 2,5 \mathrm{mM}-$ EGTA; or 3, $1 \mathrm{mM}-\mathrm{Ca}^{2+}$ plus $5 \mu \mathrm{M}-\mathrm{TFP}$.

\section{CaM-binding proteins}

CaM-interacting proteins in the soluble fraction of vegetative cells and gamete cells (mating-pheromonetreated cells) of $\boldsymbol{R}$. toruloides were identified and the molecular species of CaM-binding proteins of the two cell types were compared. CaM-binding proteins were detected by two different procedures.

In the first procedure, CaM-binding proteins were isolated from soluble cell extracts of the two cell types by CaM-Sepharose affinity chromatography. The cell extracts, containing equal amounts of protein, were applied to the column in the presence of $\mathrm{Ca}^{2+}$, and the CaMbinding proteins were eluted with a buffer containing EGTA. The affinity-purified proteins from the two cell types were analysed by SDS-PAGE (7.5\% acrylamide gel) and visualized by Coomassie blue staining (Fig. $2 a$ ). The major CaM-binding proteins of the vegetative cells detected by this procedure had molecular masses of 103 and $96 \mathrm{kDa}$. In the pheromone-treated cells, major bands of 40 and $38 \mathrm{kDa}$, and minor bands of 92 and $60 \mathrm{kDa}$, were seen in addition to those present in the vegetative cells. The bands common to the two cell types were more intense in the gamete cells (Fig. $2 a$ ).

In the second procedure for the detection of CaMbinding proteins, equal amounts of soluble protein samples prepared from the vegetative and the gamete cells were resolved by SDS-PAGE (12.5\% acrylamide), and the CaM-binding proteins were labelled with ${ }^{125} \mathrm{I}$ $\mathrm{CaM}$ after removing SDS from the gel (gel overlay method) (Fig. 2b). The binding of labelled CaM to the proteins in the gel was $\mathrm{Ca}^{2+}$-dependent, and it was completely inhibited by TFP. This technique has been used for detecting CaM-binding proteins of mammalian cells, and is a very sensitive and specific method (Glenny $\&$ Weber, 1985). The proteins observed by the gel overlay method were basically similar to those isolated by $\mathrm{CaM}$ affinity chromatography, except that the gel overlay 
method gave greater sensitivity of detection. Most of the affinity-purified $\mathrm{CaM}$-binding proteins were detected by the gel overlay method, showing the validity of the gel overlay procedure in the detection of CaM-binding proteins.

The major CaM-binding proteins of the vegetative cells detected by the gel overlay method had molecular masses of 103, 96, 58, 41, 35, 28 and $22 \mathrm{kDa}$ (Fig. $2 b$ ). The CaM-binding protein bands of the gamete cells were generally more intense than those of the vegetative cells. Among these, the proteins with molecular masses of 103 and $96 \mathrm{kDa}$ were especially more prominent in the gamete cells. In addition, a few $\mathrm{CaM}$-binding proteins (molecular masses of 138, 46, 40,34, 25, 23 and $21 \mathrm{kDa}$ ) were unique to the gamete cells, and others (molecular masses of 58 and $22 \mathrm{kDa}$ ) to the vegetative cells. However, correlation of the proteins of the two samples is not clear, since most bands in the two lanes did not share exactly the same mobility. Slight differences in electrophoretic mobility may be due to differences in protein modification such as phosphorylation.

The results indicated that the expression of many $\mathrm{CaM}$-binding protein genes is under the control of the mating pheromone. Part of the differentiation-specific proteins may be involved in the organization of mating tubes, a characteristic morphology of the gamete cell. Our results suggest that $\mathrm{CaM}$ may play important roles not only in the cellular processes of the vegetative growth, but also in sexual differentiation. It has been shown that the sexual differentiation of $R$. toruloides is extremely sensitive to the $\mathrm{CaM}$ antagonist TFP (Miyakawa et al., 1986).

Some proteins (e.g. 92 and $38 \mathrm{kDa}$ species of the gamete cells) were visible only in the affinity-purified proteins. These proteins might be subunit proteins associated with CaM-binding proteins.

$\mathrm{CaM}$ prepared from bovine brain was used for the experiments. The use of $\mathrm{CaM}$ from different species for the detection of yeast $\mathrm{CaM}$-binding proteins may cause a problem if there are any differences in the specificity of recognition. It was shown genetically, however, by Ohya \& Anraku (1989) that chicken CaM is functional in the yeast $S$. cerevisiae, indicating that $\mathrm{CaM}$ from higher organisms can interact with $\mathrm{CaM}$-binding proteins of lower eukaryotes.

\section{$\mathrm{Ca}^{2+}$ - and CaM-dependent protein kinase}

$\mathrm{Ca}^{2+} / \mathrm{CaM}$-dependent protein kinase activity in the $\mathrm{CaM}$-binding proteins was measured using $\kappa$-casein as substrate (Fig. 3). Protein kinase requiring both $\mathrm{Ca}^{2+}$ and $\mathrm{CaM}$ for activity was present in this preparation. The activity was strongly inhibited by TFP. Mammalian

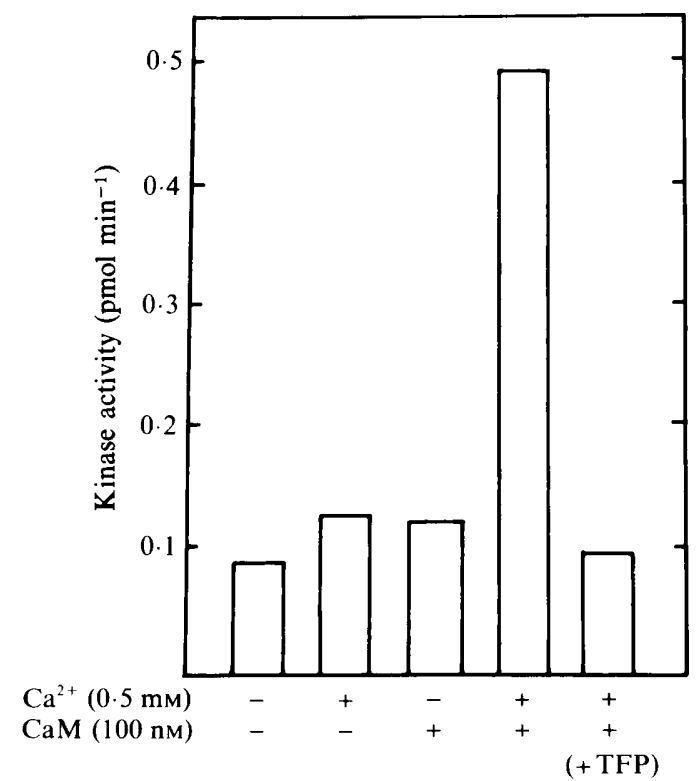

Fig. 3. $\mathrm{Ca}^{2+} / \mathrm{CaM}-$ dependent protein kinase of the CaM-affinitypurified proteins. Protein kinase activity was measured using $\kappa$-casein as substrate and $\left[\gamma^{-32} \mathrm{P}\right] \mathrm{ATP}$ as phosphate donor.

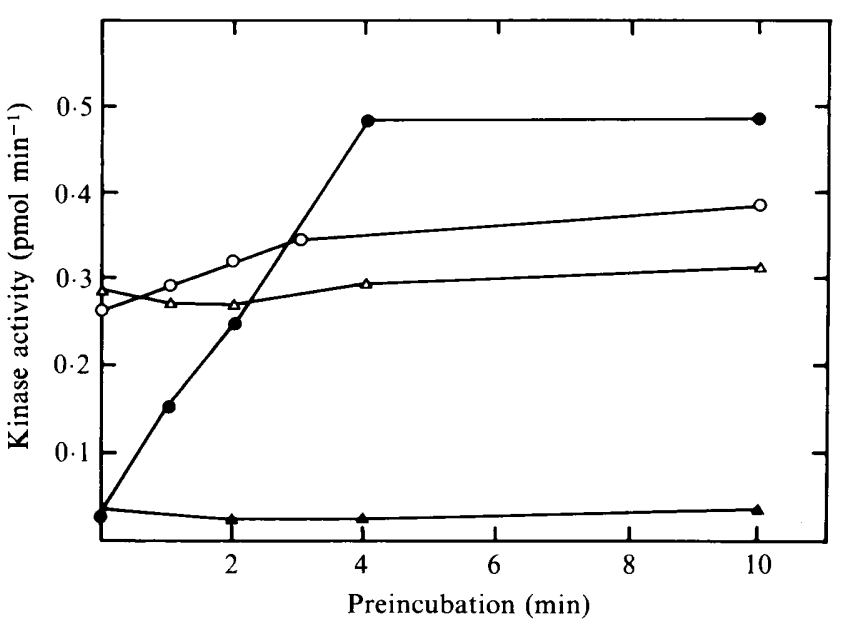

Fig. 4. Effect of preincubation conditions on the activity of $\mathrm{Ca}^{2+} / \mathrm{CaM}$ protein kinase of $\boldsymbol{R}$. toruloides. CaM-affinity-purified proteins were preincubated with nonradioactive ATP in the presence $(\mathrm{O}, \boldsymbol{O})$ or absence $(\triangle, \Delta)$ of $\mathrm{Ca}^{2+} / \mathrm{CaM}$ for various periods. $\left[\gamma-{ }^{32} \mathrm{P}\right] \mathrm{ATP}$ and $\kappa$ casein were added to the mixture and protein kinase activities were determined. The assay was performed in the presence of $\mathrm{Ca}^{2+} / \mathrm{CaM}$ for total kinase activity $(O, \triangle)$ and in the presence of $\operatorname{EGTA} / \operatorname{TFP}(\boldsymbol{O}, \Delta)$ for $\mathrm{Ca}^{2+} / \mathrm{CaM}$-independent kinase activity.

type II $\mathrm{Ca}^{2+} / \mathrm{CaM}$-dependent protein kinase has been reported to be regulated by autophosphorylation, changing its $\mathrm{Ca}^{2+} / \mathrm{CaM}$-dependence (Lai et al., 1986; Lou et al., 1986; Schworer et al., 1986). We tested whether the yeast protein kinase has a similar autoregulatory property. The affinity-purified enzyme was preincubated in the 


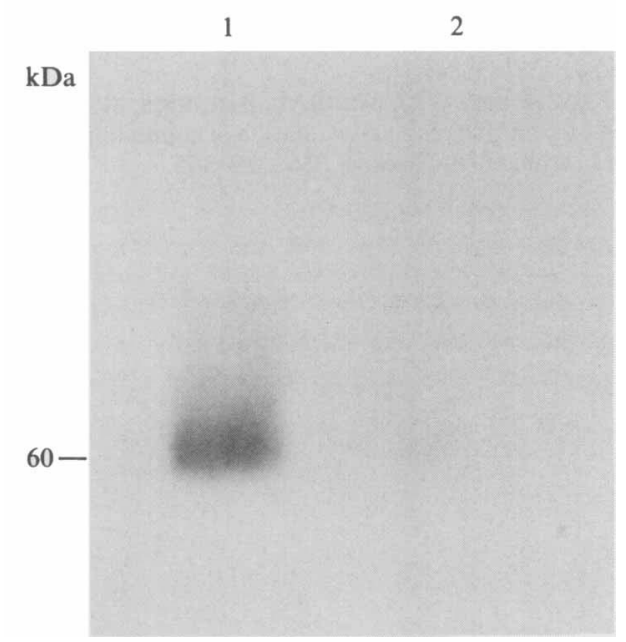

Fig. 5. Endogenous phosphorylation of CaM-binding proteins. CaMbinding proteins were phosphorylated in the presence (1) and absence (2) of $\mathrm{Ca}^{2+} / \mathrm{CaM}$. The labelled proteins were analysed by SDS-PAGE $(10.0 \%$ gel) and detected by autoradiography.

presence and absence of the kinase activators. After various periods of preincubation, kinase activity was determined in the presence of $\mathrm{Ca}^{2+}$ and $\mathrm{CaM}$ (for total kinase activity), in the presence of EGTA and TFP (for $\mathrm{Ca}^{2+} / \mathrm{CaM}$-independent protein kinase activity). The activity of protein kinase became independent of the activators very rapidly (within $4 \mathrm{~min}$ ) during the incubation (Fig. 4). For the conversion to occur, all three of $\mathrm{Ca}^{2+}, \mathrm{CaM}$ and ATP had to be present during the preincubation (data not shown).

Protein species endogenously phosphorylated by the incubation of the CaM-binding proteins were analysed. Labelled proteins were separated by SDS-PAGE after phosphorylation of the CaM-binding proteins in the absence of $\kappa$-casein. Protein with a molecular mass of $60 \mathrm{kDa}$ labelled in the $\mathrm{Ca}^{2+} / \mathrm{CaM}$-dependent manner was present in the CaM-binding proteins (Fig. 5). All of the above-described properties of the $\mathrm{Ca}^{2+} / \mathrm{CaM}$-dependent protein kinase are very similar to those of mammalian type II $\mathrm{Ca}^{2+} / \mathrm{CaM}$-dependent protein kinases which have been demonstrated to be regulated by autophosphorylation (Lai et al., 1986; Lou et al., 1986; Schworer et al., 1986). The autoregulated mammalian protein kinase is believed to be involved in the transduction of the $\mathrm{Ca}^{2+}$ signal, responding to a transient elevation of cellular free $\mathrm{Ca}^{2+}$ induced by various ligands. It is intriguing to speculate that $\mathrm{Ca}^{2+} / \mathrm{CaM}$ dependent protein kinase of $R$. toruloides may be involved in the process of sexual differentiation, responding to a transient elevation of cellular $\mathrm{Ca}^{2+}$ level induced by the mating pheromone rhodotorucine $A$
(Miyakawa et al., 1985). The presence of an autoregulatory $\mathrm{Ca}^{2+} / \mathrm{CaM}$-dependent protein kinase with properties very similar to those described here has also been found in S. cerevisiae (Miyakawa et al., 1985).

\section{References}

AbE, K., KusaKa, I. \& FukUI, S. (1975). Morphological change in the early stages of the mating process of Rhodosporidium toruloides. Journal of Bacteriology 122, 710-718.

Baum, P., Furlong, S. \& Bayers, B. (1986). Yeast gene required for spindle pole body duplication: homology of its product with $\mathrm{Ca}^{2+}$ binding proteins. Proceedings of the National Academy of Sciences of the United States of America 83, 5512-5516.

Bolton, A. E. \& HunTER, W. M. (1973). The labelling of proteins to high specific radioactivities by conjugation to a ${ }^{125}$ I-containing acylating agent: application to the radioimmunoassay. Biochemical Journal 133, 529-539

Davis, N. N., Urdea, M. S., Masiarz, F. R. \& Thorner, J. (1986). Isolation of the yeast calmodulin gene: calmodulin is an essential protein. Cell 47, 423-431.

GLENNEY, J. R., JR \& WeBER, K. (1983). Detection of calmodulinbinding polypeptides separated in SDS-polyacrylamide gels by a sensitive ${ }^{125}$ I calmodulin gel overlay assay. Methods in Enzymology 102, 204-210.

Gopalakrishna, R. \& ANDERson, W. B. (1982). Ca $^{2+}$-induced hydrophobic site on calmodulin: application for purification of calmodulin by phenyl-sepharose affinity chromatography. Biochemical and Biophysical Research Communications 104, 830-836.

KamiYa, Y., Sakurai, A., Tamura, S., Takahashi, N., Abe, K., TsuchiYa, E., Fukui, S., Kitada, C. \& Fujino, M. (1979). Structure of rhodotorucine $A$, a peptidyl factor inducing mating tube formation in Rhodosporidium toruloides. Agricultural and Biological Chemistry 43, 363-369.

LAEMMLI, U. K. (1970). Cleavage of structural proteins during the assembly of the head of bacteriophage T4. Nature, London 227, 680685.

LaI, Y., Nairn, A. C. \& Greengard, P. (1986). Autophosphorylation reversibly regulates the $\mathrm{Ca}^{2+} /$ calmodulin-dependence of $\mathrm{Ca}^{2+} / \mathrm{cal}-$ modulin-dependent protein kinase II. Proceedings of the National Academy of Sciences of the United States of America 83, 4253-4257.

Lou, L. L., Lloyd, S. J. \& Shulman, H. (1986). Activation of the multifunctional $\mathrm{Ca}^{2+} /$ calmodulin-dependent protein kinase by autophosphorylation: ATP modulated production of an autonomous enzyme. Proceedings of the National Academy of Sciences of the United States of America 83, 9497-9501.

Miyakawa, T., Nishihara, M., Tsuchiya, E. \& Fukui, S. (1982). Role of the metabolism of the mating pheromone in sexual differentiation of the heterobasidiomycete Rhodosporidium toruloides. Journal of Bacteriology 151, 1184-1194.

MiYakawa, T., Tachikawa, T., Jeong, Y. K., Tsuchiya, E. \& Fukui, S. (1985). Transient increase of $\mathrm{Ca}^{2+}$ as a signal for mating pheromone induced differentiation in the heterobasidiomycetous yeast Rhodosporidium toruloides. Journal of Bacteriology 162, 13041306

Miyakawa, T., Tachikawa, T., Akada, R., Tsuchiya, E. \& Fukui, S. (1986). Involvement of $\mathrm{Ca}^{2+} /$ calmodulin in the sexual differentiation induced by mating pheromone rhodotorucine $A$ in Rhodosporidium toruloides. Journal of General Microbiology 132, 1453-1457.

Miyakawa, T., OKa, Y., Tsuchiya, E. \& Fukui, S. (1989). Saccharomyces cerevisiae protein kinase dependent on $\mathrm{Ca}^{2+}$ and calmodulin. Journal of Bacteriology 171, 1417-1422.

OHYA, Y. \& ANRAKU, Y. (1989). Functional expression of chicken calmodulin in yeast. Biochemical and Biophysical Research Communications 158, 541-547. 
Schworer, C. M., Colbram, R. J. \& Sorderling, T. R. (1986). Reversible generation of a $\mathrm{Ca}^{2+}$ (calmodulin)-dependent protein kinase II by an autophosphorylation mechanism. Journal of Biological Chemistry 261, 8581-8584.

Takeda, T. \& Y AMAmoto, M. (1987). Analysis and in vivo disruption of the gene coding for calmodulin in Schizosaccharomyces pombe.
Proceedings of the National Academy of Sciences of the United States of America 84, 3580-3584.

Weiss, B., Prozialeck, W., Cimino, M., Barnette, M. S. \& Wallace,

T. L. (1980). Pharmacological regulation of calmodulin. Annals of the New York Academy of Sciences 356, 319-345. 